\title{
REVIEW OF SELECTED METHODS OF SUPPORTING DECISION-MAKING PROCESS IN THE CONSTRUCTION INDUSTRY
}

\begin{abstract}
A. DZIADOSZ ${ }^{1}$ A. KOŃCZAK ${ }^{2}$
The problems related to construction production are multi-faceted and complex. This has promoted the search for different methods/approaches for analizing the data which supports the decision-making process in the construction industry. In the article the authors focus their attention on well-known methods and tools, and on some new approaches to solving decision-making problems. The aim of the article is to analyze the methods used to analyse data in a construction company, convey their advantages and disadvantages, and specify the degree of efficiency in the discussed area.
\end{abstract}

Keywords: decision- making process, variant analysis, decision support methods, case-based reasoning

\section{INTRODUCTION}

Construction production itself is characterized by strong differentiation. Due to the multiple aspects of problems which arise in the industry, the methods or approaches researched must support both data analysis and the decision-making process. In order to improve the decision-making process, we use widely available, well-known methods and techniques and provide additional arguments which support adoption of the given solution. In the literature we find a set of methods which support the decision-maker to a different extent, having research tools developed in varying degrees which require proper preparation of the input data in order to meet the additional assumptions.

\footnotetext{
${ }^{1}$ MSc., PhD., Eng., Poznan University of Technology, Institute of Structural Engineering, Piotrowo 5 Street, 60-965 Poznan, Poland, e-mail: agnieszka.dziadosz@put.poznan.pl

${ }^{2}$ MSc., PhD., Eng., Poznan University of Technology, Institute of Structural Engineering, Piotrowo 5 Street, 60-965 Poznan, Poland, e-mail: aneta.konczak@put.poznan.pl
} 
The variety of subjects is large. It can be considered that supporting technologies of the decisionmaking process can be used at all decision-making stages, i.e. from strategic goals, through to the tactical goals and ending with operational goals. The following issues can be considered fundamental decision-making problems: selection of construction equipment, building location, construction technique, building materials and elements, and participants in the investment process, as well as synchronization of deliveries, the choice of the contactor's tender strategy, etc.

Due to the significant number of available methods, the following questions arise: which technique should be chosen and what magnitude of error can occur using the specific tool. The aim of this article is to show the methods that can be successfully used in construction companies wishing to standardize the investment process [11]. However, the article does not show the total cross section of approaches and techniques for supporting the decision-making process. The article outlines the topic and contributes to the start of a discussion about the possibility of using experience from other scientific fields and applying that knowledge to the construction industry (such as methods of operations research, where decision trees are successfully used). The article presents some examples of relatively affordable and intelligible decision-making methods that can improve business activities as well as improve work in building processes [1 - 41].

\section{LEVELS OF SELECTION STRATEGY IN THE DECISION-MAKING PROCESS}

The decision-making process is one of the most important aspects of a successful and sustainable company. The proper selection is essential to maximize the efficiency of measures which will increase economic impact and improve the workflow. Conclusive selections can be carried out at different decision-making levels. Some projects may relate to the overall goals related to company policy. At this level, decisions are most often characterized by uncertainty of the situation and the decision-making process concerns the long-term perspective. At the tactical level decisions often require the analysis of many criteria and they are repeatedly characterized by the subjectivity, preference and experience of the decision maker. Selection made at the operational level is the best position for decision-making, due to repeatability and routine. Each level has a different (in terms of quantity and quality) set of the output data, therefore different approaches are used in resolving problems (Figure 1). 
Problems with decisions can be analyzed according to the following three conditions:

- confidence - decision-makers know the consequences,

- risk - the probability of the occurrence of the consequences is known,

- uncertainty - the decision maker has no knowledge of the probability of the result.

\section{QUALITYOF INFORMATION}

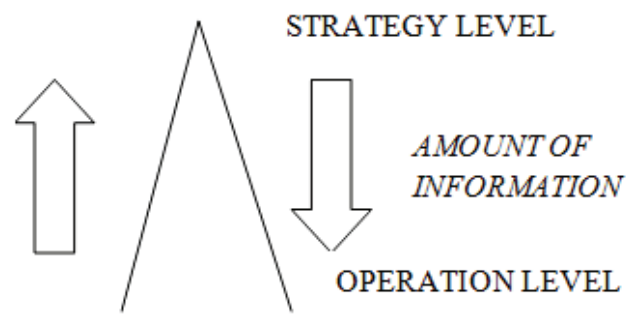

Fig. 1. Dependence: quantity-quality of information; source: author's work based on [10-12]

It is impossible to discuss all the methods of decision-making support in one article. Moreover, it is difficult to compare the methods due to the varying degrees of the complexity of calculations, inter alia, the possibility of actual implementation or due to possible flaws in the methods. According to the author's opinion, the problems discussed in the article can start further discussion about the application of methods for decision-making support at various stages in construction projects. The article includes examples that can contribute to the improvement of investment projects to a greater or lesser extent. The main goal is to present the quality of the obtained results as well as the usefulness of the data in the decision-making process.

\section{RESEARCH AREAS AND CRITERIA OF METHOD SELECTION}

As mentioned in the introduction, the organization of construction production is characterized by significant differentiation and multiple aspects. The basic areas of scientific research can include the following:

- Construction company (including quality assurance systems, partnering, organizational structures, definition of operational risk, etc.),

- Construction projects (automation, organization, construction work safety, failure, network models, modeling by fuzzy durations of construction work, quality control, time and cost 
monitoring of the construction project, logistics, environmental protection, probabilistic models of the construction processes, selection of contractors, developers' construction, transportation etc.),

- Knowledge of building materials (cement production, industrial waste, protection of buildings against heat, etc.),

- The construction market/projects (including the designing process),

- Tendering/orders (construction contracts, legal procedures),

- Scheduling (planning the workflow - organizational method/system, critical path method, time buffers),

- Cost calculation (calculation, standardization, setting the ratio of indirect costs),

- Maintenance of building facilities, service life of building facilities (building facility life cycle, LCCA, sustainable development).

The percentage share of the main areas of research (as an example) has been developed on the basis of conference papers from the TOB conferences, which took place in Krakow (2004) (Fig.2.) and in Gdańsk (2007) (Fig. 3.), under the auspices of the Section of Engineering of Construction Projects (formerly: Section of Organization and Management in the Construction Industry). It can be noted that the thematic scope of research areas increased towards the service life and maintenance of building facilities and better planning of construction projects, including scheduling and cost controlling (the Earned Value Method). There is also more research conducted in terms of logistics, supply coordination and allocation of resources [3, 9, 29].

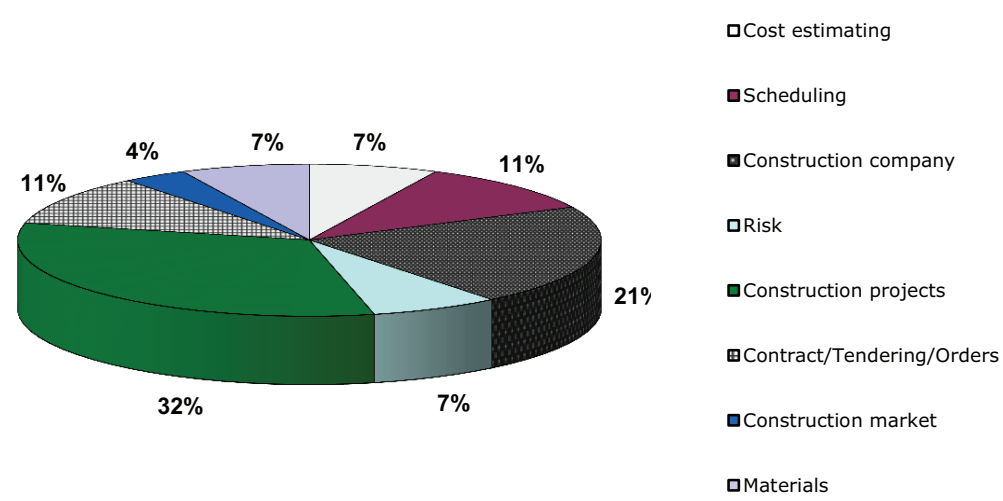

Fig. 2. Engineering of Construction Projects Kraków (2004 r.); source: authors' work 


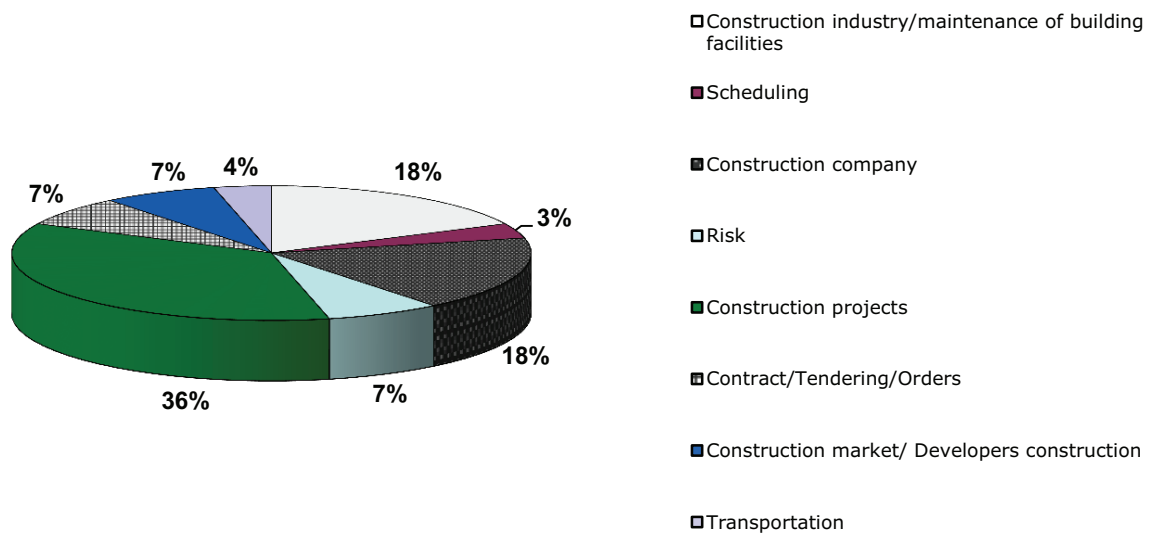

Fig. 3. Engineering of Construction Projects, Gdańsk (2007 r.); source: authors’ work

Therefore, it might be concluded that the scope of the research areas is relatively large, as are the variety of methods and techniques. We can go from simple computational methods to those more sophisticated. The basic characteristics of available tools include the following:

- Comprehensibility, quality and ease of interpretation of obtained results,

- Applied mathematical apparatus (appropriate software, tools for simulations),

- Ability to meet the stringent assumptions (data type, range of sample size, etc.), type and scope of data input,

- Ease of verification and the subsequent implementation of data for planning and execution of a construction project.

Many methods rely on some subjective judgements by the decision-maker, which can cause errors in the final result estimation due to the decision-making conditions, i.e. confidence, uncertainties, risks or preferences. Hence, there is noticeable a trend toward searching for methods and techniques in other fields and industries, such as economics or biology (i.e. the neural networks). Attempts are being made to combine different techniques to create so-called "hybrids" [7].

\section{OVERVIEW OF SELECTED METHODS FOR DECISION-MAKING SUPPORT}

The article focuses on methods which are relatively intelligible and easy-to-use, and will present excellent tools to assist in a decision-making process in a construction company, e.g. the selection 
of the final investment variant or the method of construction project realization as well as contractor selection. These include the decision trees and the multi-criteria methods.

\subsection{MULTI-CRITERIA SUPPORT OF THE DECISION-MAKING PROCESS}

As its name suggests, one of the main advantages of the multi-criteria decision-making methods is the possibility to separate a lot of criteria, regardless of the character of the data. These methods enable the ability to take into account the qualitative data in the decision making process, and convey it in linguistic form. The most popular methods are the following: Promethee, Elektra, AHP, Copras-G, etc. as well as fuzzy sets. A review of the available methods and the scope of their applications can be found in the following works: [2, 4-8, 10, 12, 15-18, 20-32, 34, 35, 37-39, 41]. However, one of the works published in the Journal of Civil Engineering and Management [34] is highly recommended, as it concerns the identification and verification of the multi-criteria methods on some selected examples.

These methods are used in various industries and fields, mainly (thanks to the possibility of examining the problems of the multidimensional selection) when considering the qualitative and quantitative factors reflecting the requirements of the decision maker. The fundamental advantage of these methods is that they accurately reflect the nature of the examined phenomenon, though their ability to indicate the correct prognostic values is doubted. It is connected with the considerable subjectivity involved when determining the weights and preferences of the variants during the course of performing calculations. It has been proved in the following works: $[4,5]$.

The obtained results give only a rough estimate and a preliminary line-up of projects and because of the individual approach of the decision-maker to solve a problem, they may be flawed forecasts. These nuances do not diminish the potential nor the advantages of the mentioned methods. The article presents one method, in a lesser-known Polish publication, called the Copras-G method. The procedure of the Copras-G method is based on building a decision-making matrix where, for each construction project comparison, two values are assigned - the upper limit and the lower limit. Then the weights must be specified for each attribute. The next step leads to normalize the values in the matrix and estimates the sum of the values of attributes depending on their character (Table 1). The examples of the application of the method can be found in the literature [5, 23, 37-39] and in the example below (Table 1). 
Table 1. Contractor selection using Copras-G; source: authors' work

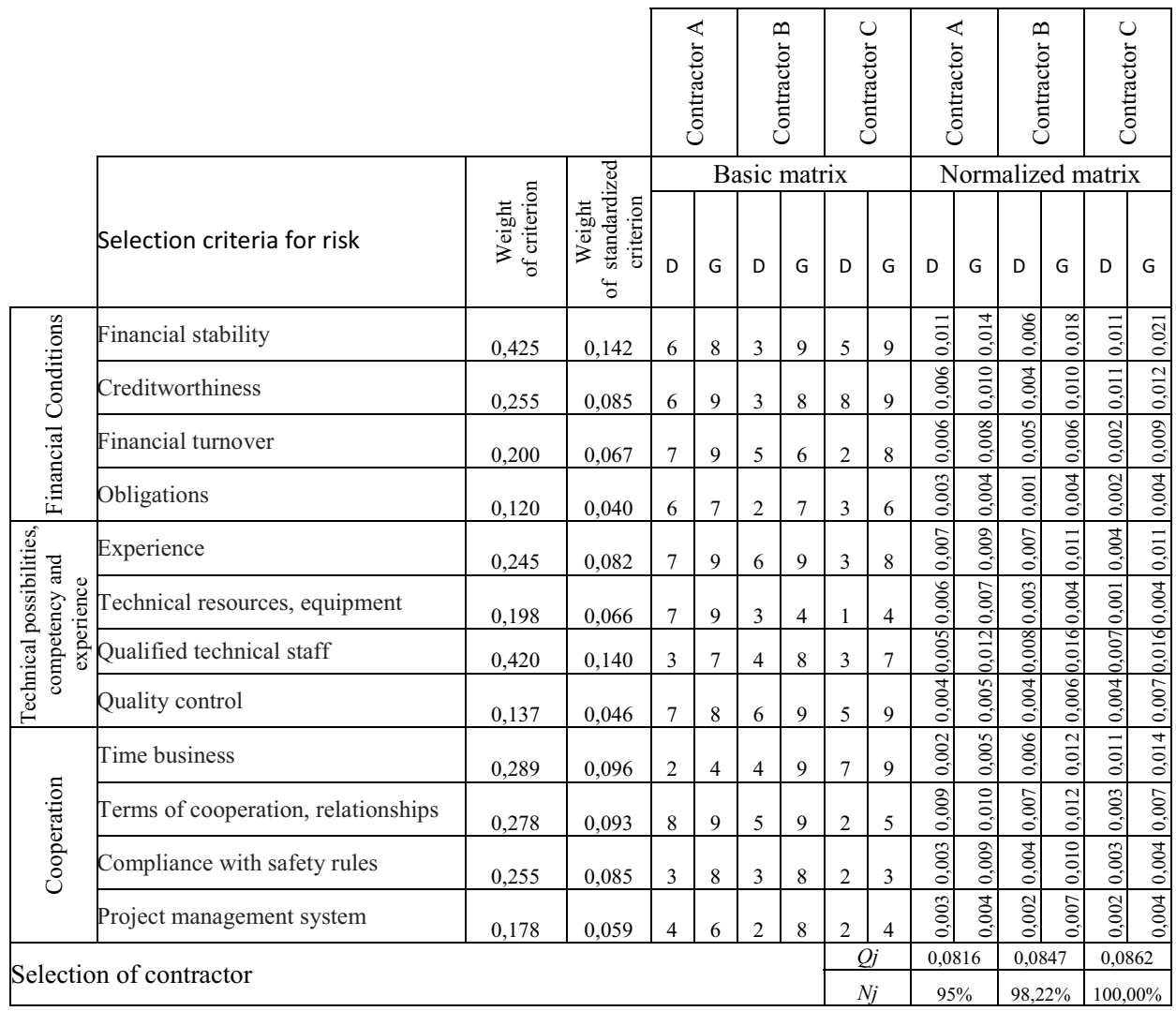

The author of the work [40] presents an alternative to the multi-criteria methods in the selection of investment variants by the application of fuzzy sets. The theory of fuzzy sets was invented by Lotfi Zadeh to describe vague and poorly defined concepts. The concept of the fuzzy set is a generalization of the concept of a sharp set, adopting the characteristic function attached to a set and assumes, in addition, the limited states 0 or 1 and intermediate values. The created foundations of fuzzy sets allow natural phenomena in nature to be described in an imprecise and ambiguous way, just like "a tall building". They enable the formal recording of linguistic variables in the form of a measurable size by using a fixed conceptual apparatus of the fuzzy sets theory. Initially, each element should be specified in each area of consideration (space, set) for the subsequent determination of its attachment to the set. The attachment functions are used (noted by, among others, a graph in the form of continuous operation) to determine the attachment of each element 
to a set. The examples of the application of fuzzy sets in the decision-making process in the construction industry can be found in the following works [6, 7 20-22, 40, 41].

\subsection{DECISION-MAKING TREES}

The usefulness of trees stands on the fact that on one diagram we can summarize all events that may occur as a result of making particular decisions and the occurrence of some individual states. The decision-making trees method is a non-parametric method which is especially useful when dealing with decision-making problems with multiple, branching variants.

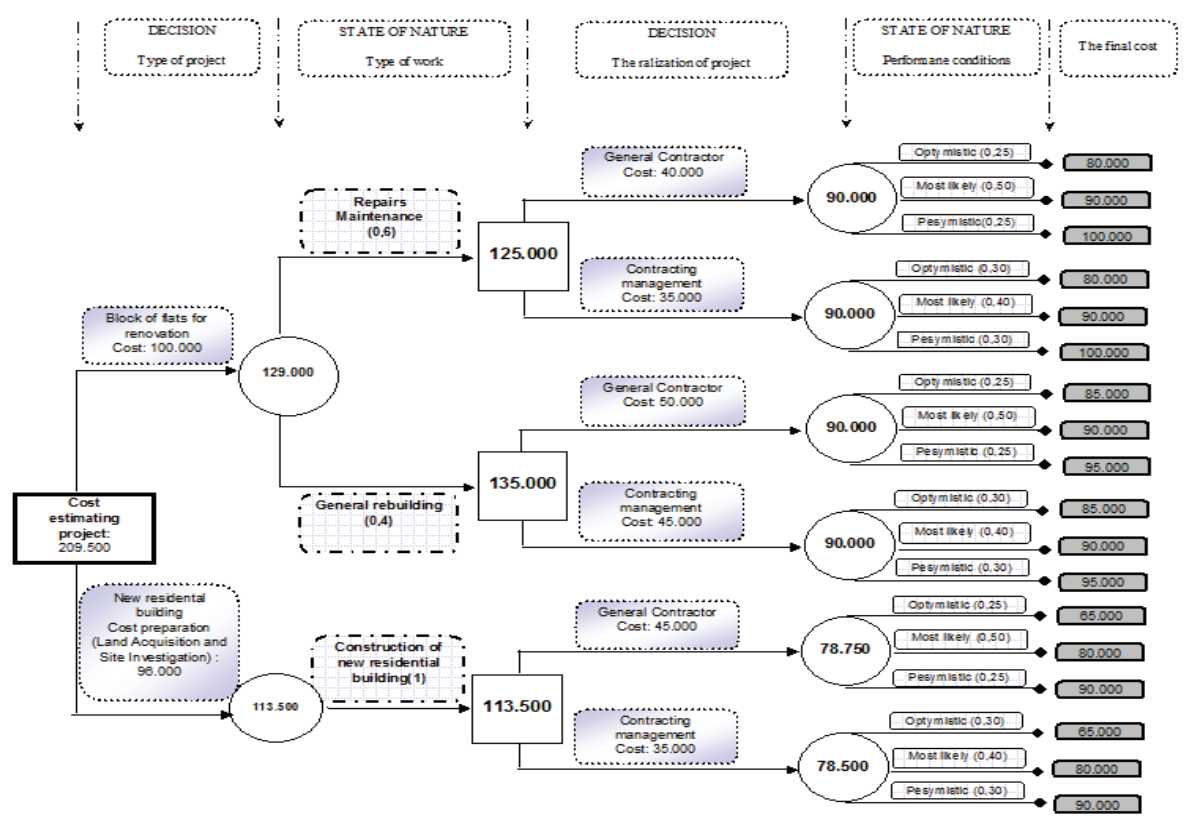

Fig. 4. Decision-making tree for investment project selection; source: authors’ work

The basic features include the simplicity and comprehensiveness of the presentation of variants of decisions and their consequences as well as the possibility of using probability properties. They are a convenient form of presenting a problem when dealing with a decision involving risk. There are some special graph forms consisting of branches and nodes. The Expected Monetary Value is the main criterion used for analysis of the trees, which can be either maximized or minimized. In addition, with this method we can examine the process of sequential decision-making 
(multi-stages) in conditions of risk and the connected activities in the cause-effect sequences. The principles of the building of dendrites and their analysis are presented in the following works $[24,32$, and 33] as well as in the example (Figure 4).

\subsection{CASE- BASED REASONING}

Case-based reasoning (CBR) is an example of the approach to decision-making support which can be based on a DSS system. It belongs to the group of approaches in the field of artificial intelligence, the aim of which is to learn and solve problems from experience (between the stages of introducing a rule system and the machine learning). The CBR consists of a knowledge base containing information from previous real-life cases, and is based on a precedent. The use of the CBR aims to provide the skills to cope with new situations, allows for objectivism and gives a critical look into specific situations and the possibility for interpretation on the basis of past experience. Its application is described in the work [1]. The learning cycle is based on the data from analogous cases, results from the implementation of the solution, the development and saving/recording of knowledge in the base in order to be able to use it again in the future (Figure 5) [19]. The description of phenomena might be based on numerical data as well as text, symbols, plans, etc. This approach is becoming widely used in, among others, medicine, aviation and the navy. [1, 19, and 36].

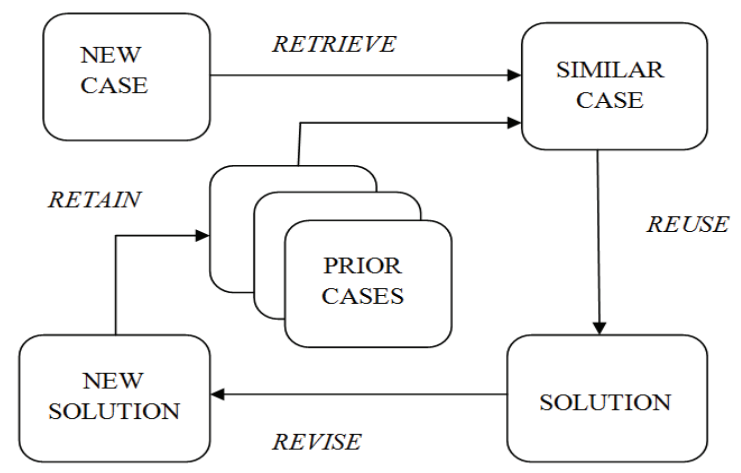

Fig. 5. Learning cycle in CBR method [36]

The use of information derived from the knowledge base is simple and allows easy access to similar cases from the past. Therefore, the CBR approach may be used in most cases in which there is a possibility to find similar scenarios; knowing that this example will result in normal and 
expected consequences of a decision maker. In these cases expert knowledge is an important factor. Case-based Reasoning can be applied at all levels of the decision-making process.

If the input data in the knowledge base expands on the information from the observation of phenomena it is possible to connect the CBS method with computer simulations (the Monte Carlo method), creating the so-called "hybrid". This approach will enable the achievement of synergies and a decision maker will be able to analyze the information from the past under the new situation. This application may take place at the operational level, where a series of data are received without any problems. These data will require a description and the statistical inference.

The example of a hybrid approach in planning the building process (presented in the article) is the application of information from the supply of concrete mix to a construction site, which is also discussed in the following works [13, 14]. Each delivery is characterized by varying parameters of the process (e.g. weather, temperature, type of concrete, number of concrete mixer trucks, their volume, etc.) contained in the knowledge base (Table 2).

Table 2. Fragment of a knowledge map; source: authors' work

\begin{tabular}{|c|c|c|c|c|c|c|}
\hline No. & Pour type & Tempe-rature & Weather & $\begin{array}{c}\text { Volume } \\
\text { of truck }\end{array}$ & No. of trucks & $\begin{array}{c}\text { Time } \\
\text { of the ride }\end{array}$ \\
\hline 1 & BAS & Medium & Sunshine & 9 & 7 & $1: 17$ \\
2 & BAS & Medium & Sunshine & 9 & 7 & $1: 01$ \\
3 & BAS & Medium & Overcast & 9 & 7 & $0: 59$ \\
4 & BAS & Medium & Overcast & 9 & 7 & $1: 12$ \\
5 & BAS & Medium & Overcast & 9 & 7 & $1: 02$ \\
\hline
\end{tabular}

The base also included the travel times of particular concrete mixer trucks thanks to which it was possible to simulate the delivery of concrete to a construction site (using a computer software, among others: MicroCyclone and FlexSim). The simulation of the process supports the selection of the best variant in the selection of the number of concrete mixer trucks, which translates to minimizing rental costs of concrete mixer trucks and maximizing concreting work efficiency by eliminating concrete mixer trucks' queuing time and downtime of the pump trucks). It was concluded that with the similar parameters, two fewer concrete mixer trucks could be rented, which would save the truck rental cost and reduce the queues, thus creating more efficient workflow.

In order to get the results, the entire concrete delivery cycle had to be monitored; getting to know the timing of individual tasks in the process (loading of concrete mix from the factory, transportation to a construction site, the queue in front of the pump truck, unloading, washing 
a concrete mixer truck, coming back to a factory, the queue in the front of a concrete mixer) and saving/recording their characteristic parameters. The tasks are presented in the simulation program FlexSim (Figure 6). The program is dedicated mainly to logistics needs, therefore, it does not reflect the process course visually. It should be mentioned that the simulation model is a subjective interpretation of reality and enriching them with details (which are not relevant for the simulation) increases calculation time and hinders the phase of analysis and inference. However, the hybrid approach (presented in the article) is clear and allows for analyzing a process both in the optimistic scenario (i.e. without hindrance), the most likely/probable scenario (normal) and under the conditions of the pessimistic scenario, which in turn will allow for preparation of the appropriate resources for different variants.

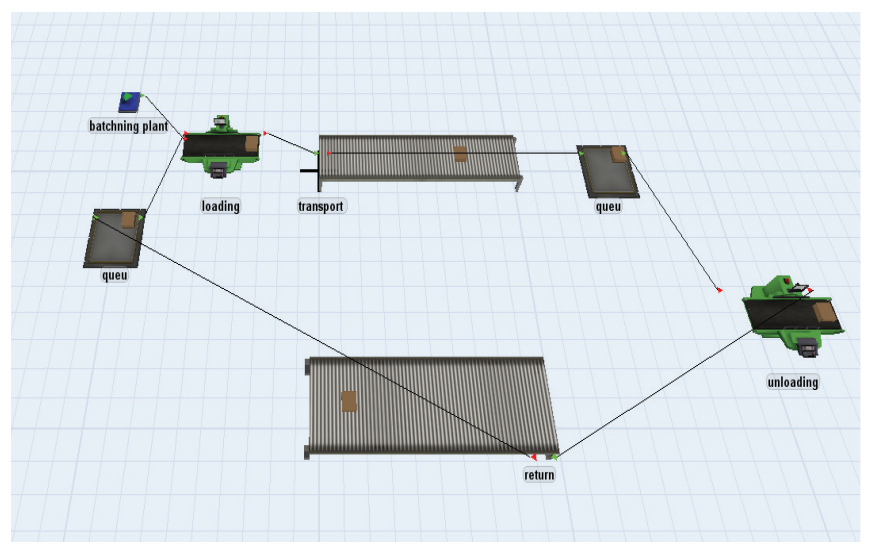

Fig. 6. Simulation of the delivery process of concrete mix on a construction site in the FlexSim program; source: authors' work

\section{CONCLUSION}

For the analysis the authors selected three methods supporting the decision-making process in a construction company for various decision problems: the selection of contractors, selection of investment projects and the simulation of concrete mix delivery to a construction site. It should be emphasized that the character of the presented methods prevents their mutual comparison. Each of these methods has a different course of calculations, requirements and assumptions as well as different kinds of decision-making problems. However, each of these methods can be safely used at all levels of the decision-making process. It is worth mentioning that the methods which allow 
in the analysis are dependent on the subjective assessment of a decision maker, but they do allow for examining the problem in the multi-aspects method. Hence, their popularity is very high, as confirmed by the publications cited in the article. It is also worth remembering that high precision (resulting from the significant complexity of the method) is not always needed. Increasing the number of variables in the regression or the number of layers in the neural networks does not always produce expected or accurate results. The primary goals of analyses, comprehensiveness and ease of implementation of the results are very important. We sometimes need only data estimates that provide us with additional evidence to make a particular decision.

\section{REFERENCES}

1. A. Aamodt, ,E. Plaza, "Case-Based Reasoning: Foundational Issues, Methodological Variations, and System Approaches", AI Communications. IOS Press, Vol. 7: 1, s. 39-59.

2. R. Bucoń, Zastosowanie rozszerzonej rozmytej metody AHP do ustalenia istotności kryteriów oceny stanu eksploatacyjnego obiektów mieszkalnych, Warsztaty Inżynierów Budownictwa, „Problemy przygotowania i realizacji inwestycji budowlanych", Puławy, 185-190, 2009.

3. M. Dytczak, G. Ginda, Construction schedule of works as combinatorial optimisation problem, Technical Transactions, Civil Engineering, 2-B, pp 283-290, 2014.

4. A. Dziadosz, Ocena i selekcja inwestycji budowlanych przy wykorzystaniu analitycznego procesu hierarchicznego - AHP, Czasopismo Techniczne z.1-B, zeszyt 21 (ROK 105), 41-51. 2008.

5. A. Dziadosz., Rejment M., Wybrane aspekty selekcji przedsięwzięć budowlanych, Archiwum Instytutu Inżynierii Lądowej, Wydawnictwo Politechniki Poznańskie, 13 s. 99-107, 2012.

6. M. Gajzler, The use of fuzzy logic in decision-making systems, Foundations of Civil and Environmental Engineering, No. 5, s. 7-20, 2004.

7. M. Gajzler, Hybrydowy system doradczy dla napraw betonowych posadzek przemysłowych, rozprawa doktorska, Politechnika Poznańska 2008.

8. M. Gajzler, Dziadosz A., Szymański P., Problematyka wybory metody wspomagającej podejmowanie decyzji w budownictwie, Czasopismo Techniczne z.1-B, zeszyt 2 (ROK 107), 69-84, 2010.

9. P. Jaskowski, M. Tomczak, Assignment problem and its extension for construction project scheduling, Technical Transactions, Civil Engineering, 2-B, pp 241-248, 2014.

10. O. Kapliński, Development and usefulness of planning techniques and decision-making foundations on the example of construction enterprises in Poland, Technological and Economic Development of Economy, Vol.14, No.4, s. 492-502, 2008.

11. O. Kapliński, A. Dziadosz, J.L. Zioberski, An attempt of management process standardisation at the stage of planning and implementation of construction projects, Proc. 57th Annual Scientific Conference: scientific Problems of Civil Engineering, The Faculty of Civil and Environmental Engineering, Rzeszow University of Technology, Rzeszów - Krynica, 18-22 September, 30-31, 2011.

12. O. Kapliński i inni, Metody i modele badań w inżynierii przedsięwzięć budowlanych. Wydawnictwo PAN KILiW IPPT, Warszawa, 2007.

13. A. Kończak, J. Pasławski , "Abductive and Deductive Approach in Learning from Examples Method for Technological Decisions Making “. Procedia Engineering, No. 57/2013, s.. 583- 588.

14. A. Kończak, J. Pasławski "Hybrid approach in learning from examples in construction process design", Technical Transacionts, No. 2-B(6), s. 21-30, 2014.

15. M. Krzemiński, M. Książek, Ocena jakości wybranych obiektów budowlanych przy zastosowaniu teorii zbiorów rozmytych, [w:] Technologia i Zarządzanie w Budownictwie, Prace Naukowe Instytutu Budownictwa Politechniki Wrocławskiej nr 91, Seria: Studia i Materiały nr 20, Wrocław 2008.

16. M. Krzemiński, Książek M., Wielokryterialna analiza wybranych obiektów budowlanych wraz z analizą kryteriów oceny przy zastosowaniu metody entropii, Warsztaty Inżynierów Budownictwa, „Problemy przygotowania i realizacji inwestycji budowlanych", Puławy, 249-254, 2008.

17. M. Książek, „Analiza porównawcza wybranych metod wielokryterialnych oceny przedsięwzięć inwestycyjnych", Civil and Environmental Engineering, Vol 2, pp 555-561, 2011. 
18. M. Książek, P. Nowak, J. Rosłon, „Decision making with use of ahp method in construction” Technical Transactions, Civil Engineering, 2-B, pp31-39, 2014.

19. R Lopez De Mantaras, Ramon, et al. "Retrieval, reuse, revision and retention in case-based reasoning." The Knowledge Engineering Review 20.03 (2005): 215-240, 2005.

20. E. Plebankiewicz, Contractor prequalification model using fuzzy sets, Journal of Civil Engineering and Management,Vol. 15, No.4, s.377-385, 2009.

21. E. Plebankiewicz, Model strategii przetargowej wykonawcy budowlanego z zastosowaniem teorii zbiorów rozmytych, rozprawa doktorska, Politechnika Krakowska 2001.

22. E. Plebankiewicz, Modelling decision-making processes in bidding procedures with the use of the fuzzy sets theory, International Journal of Strategic Property Management - 2014 Vol. 18, Iss. 3, s. 307-316.

23. M. Rejment, A. Dziadosz , Selected aspects of construction project selection including risk estimation, Technical Transactions, Civil Engineering, 1-B, pp.221-228 [Wybrane aspekty selekcji przedsięwzięć budowlanych z uwzględnieniem oceny ryzyka], Czasopismo Techniczne, Zeszyt 1-B (5), ROK 2014 (111) s.221-228, 2014

24. T. Szapiro (red.), Decyzje menadżerskie z Excelem, Wydawnictwo PWE, Warszawa 2000

25. S. Shevchenko, L. Ustinovichius, A. Andruskevicius, Multi-attribute analysis of investment risk alternatives in construction, Technological end Economic Development of Economy, Vol. 14, No.3, s. 428-443, 2008

26. D., Skorupka, Duchaczek A., „Zastosowanie metody ahp w optymalizacji procesów decyzyjnych związanych z realizacją przedsięwzięć logistycznych", Zeszyty Naukowe WSOWL, nr 3 (157), s. 54-62, 2010

27. D., Skorupka, Duchaczek A., „Identification of the risk of disturbances of operation of transport infrastructure in crisis conditions", Technical Transactions, Civil Engineering, 1-B, pp 203-209, 2014.

28. A. Sobotka, K. Linczowski, Analysis of logistics for construction site supply with reinforcing steel, Technical Transactions, Civil Engineering, 2-B, pp 225-232, 2014.

29. E. Szafranko, Ocena ekspertów w analizach prowadzonych metodą AHP przy wyborze wariantów inwestycji Inżynieria Morska i Geotechnika nr 5, 2013, 400-404, 2013.

30. E. Szafranko, Zastosowanie analizy hierarchicznej w ocenie wariantów planowanej inwestycji, Archiwum Instytutu Inżynierii Lądowej, Wydawnictwo Politechniki Poznańskie, 13, s.319-331, 2012.

31. J. Szwabowski, J. Deszcz, Metody wielokryterialnej analizy porównawczej - podstawy teoretyczne i przykłady zastosowań w budownictwie, Wydawnictwo Politechniki Śląskiej, Gliwice 2001.

32. W. Szymanowski, Techniki ilościowe w zarządzaniu operacyjnym w przedsiębiorstwie, Wydawnictwo SGGW, Warszawa 2001.

33. T. Thiel, Metodyczne aspekty wielokryterialnego wspomagania decyzji w inżynierii produkcji budowlanej, rozprawa doktorska, Politechnika Poznańska, Poznań 1996.

34. Z. Turskis, M. Gajzler, A. Dziadosz, Reliability, risk management and contingency of construction processes and projects, Journal of Civil Engineering and Management, Vol. 18 (2): pp 290-298, 2012.

35. I. Watson, "Case- based reasoning is a methodology not a technology", Knowledge Based System Vol. 12, s. 303-308, 1999

36. E. Zavadskas, Risk assessment of construction project, Journal of Engineering and Management, 16, 1, 33-46, 2010 .

37. E. Zavadskas, A. Kaklauskas, Z. Turskis, J. Tamosaitiene, Multi-attribute decision-making model by applying grey number, Informatica, 20, 2, 305-320, 2009

38. E. Zavadskas, L. Ustinovichius, A. Stasiulionis, „Multicriteria valuation of commercial construction projects for investment purposes, Journal of Civil Engineering and Management”, 10, 2 (2004) 151-166.

39. K. Zima, Analiza deweloperskich przedsięwzięć budowlanych z zastosowaniem logiki rozmytej, rozprawa doktorska, Politechnika Krakowska 2008.

40. K. Zima, The concept of investment decision support model using fuzzy set theory, 11th International Conference Of Numerical Analysis And Applied Mathematics 2013: ICNAAM 2013. AIP Conference Proceedings, Volume 1558, Pp. 1307-1311, 2013. 


\section{LIST OF FIGURES AND TABLES:}

Fig. 1. Dependence: quantity-quality of information, source: authors' work based on [10-12]

Rys. 1. Zależność ilość-jakość informacji [10-12]

Fig. 2. Construction enterprises engineering, Kraków (2004 r.) source: authors' work

Rys. 2. Inżynieria przedsięwzięć budowlanych, Kraków (2004 r.)

Fig. 3. Construction enterprises engineering, Gdańsk (2007 r.), source: authors' work

Rys. 3. Inżynieria przedsięwzięć budowlanych, Gdańsk (2007 r.)

Fig. 4. Decision-making tree for investment project selection, source: authors' work

Rys. 4. Drzewo decyzyjne dla selekcji przedsięwzięć inwestycyjnych

Fig. 5. Learning cycle in CBR method [36]

Rys. 5. Cykl uczenia się w metodzie CBR [36]

Fig. 6. Simulation of delivery process of concrete mix on construction site in the FlexSim program, source: authors' work

Rys. 6. Symulacja procesu dostawy mieszanki betonowej na budowę w programie FlexSim

Tab. 1. Contractor selection using Copras-G, source: authors' work

Tab. 1. Selekcja wykonawców przy wykorzystaniu Copras-G

Tab. 2. Fragment of a knowledge map, source: authors' work

Tab. 2. Fragment bazy wiedzy 


\section{PRZEGLĄD WYBRANYCH METOD WSPOMAGAJACYCH PODEJMOWANIE DECYZJI W BUDOWNICTWIE}

Keywords: proces podejmowanie decyzji, analiza wariantów, wspomaganie decyzji, case-based reasoning.

\section{STRESZCZENIE:}

Produkcja budowlana charakteryzuje się silnym zróżnicowaniem. Ze względu na wieloaspektowość zagadnień poszukuje się metod lub podjeść, które wspomogą analizę danych oraz proces podejmowania decyzji w budownictwie. W celu usprawnienia procesu decyzyjnego możemy sięgnąć po dostępne, znane metody i techniki, dostarczające dodatkowe argumenty umożliwiające przyjęcie danego rozwiązania. W literaturze odnajdziemy zbiór metod w różnym zakresie wspomagających decydenta, mające w różnym stopniu rozbudowany aparat narzędziowy, wymagających odpowiedniego przygotowania danych wejściowych oraz spełnienia dodatkowych założeń. Celem artykułu jest ukazanie metod, które z powodzeniem mogą być stosowane w przedsiębiorstwach budowlanych dążąc do standaryzacji proces inwestycyjnego [3]. Niemniej jednak artykuł nie ukazuje całkowitego przekroju przez podejścia i techniki wspomagania podejmowania decyzji. Zaprezentowano jedynie przykłady wykorzystania stosunkowo przystępnych i czytelnych zrozumiałych metod podejmowania decyzji, które mogą usprawnić działania przedsiębiorstw i udoskonalić ich pracę w procesach budowlanych.

Wiele metod opiera się na subiektywnych opiniach decydenta, co może wpływać na błąd oszacowania końcowego wyniku wynikający z warunków podejmowania decyzji: pewności, niepewności bądź ryzyka i preferencji samego decydenta. Stąd zauważalny jest trend w kierunku poszukiwania metod i technik w innych dziedzinach i branżach m.in. w ekonomi lub biologii (tj. sieci neuronowe). Podejmowane są próby łączenia różnych technik tworząc tzw. Hybrydy [2].

W artykule skupiono uwagę na metodach stosunkowo przystępnych w wykorzystaniu, stanowiących doskonałe narzędzie wspomagające podejmowanie decyzji w przedsiębiorstwie np. przy ustaleniu strategii przetargowej, przy wyborze wykonawcy robót (drzewa decyzyjne) lub przy wyborze ostatecznego wariantu inwestowania bądź sposobu realizacji inwestycji budowlanej (drzewa decyzyjne). Zakres obszarów wykorzystania technik/metod jest zdecydowanie szerszy, mianowicie: Przedsiębiorstwo budowlane, Przedsięwzięcia budowlane, Materiałoznawstwo, Rynek budowlany, Ofertowanie/przetargi/zlecenia, Harmonogramowanie (planowanie w metodzie potokowej, łańcuch krytyczny, bufory czasu), Kosztorysowanie, Utrzymanie obiektów, eksploatacja (cykl życia obiektu, LCCA, zrównoważony rozwój), itp. Jako pierwsze omówiono metody wielokryterialnego podejmowania decyzji. Jak sama nazwa wskazuje jedną z podstawowych zalet metod wielokryterialnego podejmowania decyzji jest możliwość wyodrębnienia wielu kryteriów, niezależnie od charakteru danych. Są to jedne z nielicznych metod umożliwiające uwzględnienie w procesie podejmowania decyzji danych jakościowych, wyrażonych w postaci lingwistycznej Do najpopularniejszych metod możemy zaliczyć: Promethee, Elektrę, AHP, Copras-G itp. a także zbiory rozmyte.

Metody te są wykorzystywane w różnych branżach i dziedzinach - głównie dzięki możliwości rozpatrywania zagadnienia selekcji wielowymiarowo przy uwzględnieniu jakościowych i ilościowych czynników odzwierciedlających wymagania samego decydenta. Podstawową zaletą jest to, że metody te dobrze odzwierciedlają naturę rozpatrywanego zjawiska, aczkolwiek wątpliwość budzi ich mała zdolność do wskazywania poprawnych wartości prognostycznych. Natomiast użyteczność drzew wynika z tego, że na jednym schemacie otrzymujemy zestawione wszystkie zdarzenia, jakie mogą zaistnieć w wyniku podjęcia poszczególnych decyzji i wystąpienia poszczególnych stanów. Drzewa decyzyjne jest to metoda nieparametryczna, szczególnie przydatna w problemach decyzyjnych z licznymi, 
rozgałęziającymi się wariantami. Jako ostatnie przedstawione zostało podejście Case- based reasoning (CBR). Należy do podejść z zakresu sztucznej inteligencji, celem którego jest nauczenie się i rozwiązywanie problemów z doświadczeń (między etapem wprowadzenia systemu reguł a uczeniem maszynowym). CBR składa się z bazy wiedzy zawierającej informacje z poprzednich, analogicznych przypadków i opierających się na precedensie. Oznacza to, że wykorzystanie CBR ma posłużyć umiejętności radzenia sobie w nowych sytuacjach, obiektywnemu i krytycznemu spojrzeniu na ową sytuację oraz możliwości jej zinterpretowania na podstawie poprzednich doświadczeń, jej zastosowanie zostało opisane w [1].

Wykorzystywanie informacji zaczerpniętej z bazy wiedzy jest proste i pozwala w łatwy sposób odnieść się do analogicznych przypadków z przeszłości.

Reasumując charakter zaprezentowanych metod uniemożliwia ich wzajemne porównanie. Każda z metod cechuje się odmiennym tokiem obliczeń, wymogami i założeniami jak również rodzajem problemu decyzyjnego. Natomiast każdą z nich możemy śmiało wykorzystać na każdym szczeblu decyzyjnym. Zauważalne jest to, że metody, które pozwalają uwzględnić w analizie zmienne jakościowe uzależnione są od subiektywnej oceny decydenta, aczkolwiek pozwalają rozpatrzyć problem wieloaspektowo. Stąd tak duża ich popularność, potwierdzona przytoczonymi w artykule publikacjami. Warto pamiętać, że nie zawsze duża precyzja wynikająca ze znacznego stopnia skomplikowania metody jest potrzebna. Niekiedy wystarczają nam tylko szacunkowe dane, zapewniające dodatkowe przesłanki do podjęcia określonej decyzji.

\section{Bobliografia}

[1] A. Aamodt, E. Plaza, "Case-Based Reasoning: Foundational Issues, Methodological Variations, and System Approaches”, AI Communications. IOS Press, Vol. 7: 1, s. $39-59$.

[2] M. Gajzler, Hybrydowy system doradczy dla napraw betonowych posadzek przemysłowych, rozprawa doktorska, Politechnika Poznańska 2008.

[3] O. Kapliński, A. Dziadosz, J.L. Zioberski, An attempt of management process standardisation at the stage of planning and implementation of construction projects, Proc. 57th Annual Scientific Conference: scientific Problems of Civil Engineering, The Faculty of Civil and Environmental Engineering, Rzeszow University of Technology, Rzeszów - Krynica 2011, 18-22 September, 30-31. 